\title{
Assessment of Beef Cattle Husbandry Practices in North Shoa Zone, Amhara Region, Ethiopia
}

\author{
Getachew Kassa ${ }^{1}$, Almaz Bekele ${ }^{2 *}$, Tewodros Eshete ${ }^{1}$ and Kasahun Bekele ${ }^{1}$ \\ ${ }^{1}$ Debere Berhan University, Department of Animal science, Ethiopia \\ ${ }^{2}$ Wolaita Sodo University, Department of Animal and Range Science, Ethiopia
}

Submission: May 09, 2019; Published: May 29, 2019

*Corresponding author: Almaz Bekele, Wolaita Sodo University, Department of Animal and Range Science, P. O. Box 138, Wolaita Sodo, Ethiopia

\begin{abstract}
The study was conducted with the objectives of assessment of beef cattle husbandry practice in North Shoa Zone, Amhara Regional State. The data were collected through semi structured questionnaire, group discussions and field observation. A total of 490 households were randomly selected and interviewed by using pre-tested questioner. Statistical package for social science (SPSS 16) were used to analyze the collected data. Majority of respondents $70.0 \% 73.9 \%$ and $61.9 \%$ provide supplementary feed for their calves, manage their calves together with other animal and fatten exotic breeds respectively. Based on the respondent's response $87.6 \%$ practice culling and the main reasons of culling animals were aging $(52.2 \%)$, Infertility (10.3\%), unhealthy (22.8\%), deformed conformation $(6.2 \%)$ and unwanted color $(0.3 \%)$. Modern treatment $(85 \%)$ and government clinics were more preferred by the farmers and $89.4 \%$ of farmers vaccinate their animal. Most farmers $57.7 \%$ and $67.9 \%$ have their own grazing land and conserve both hey and straw respectively. Concentrate or industrial by product utilization was limited wheat bran utilization was zero in Basonaworana and Ankober woreda and oilseed cake also zero in Minjarshenkora, Efratanagidim and Ankober Woredas. $60.8 \%$ of the respondents provide separate house for their cattle. The intervention which will be done in the future should consider the existing traditional management and herding practices.
\end{abstract}

Keywords: Beef cattle; Husbandry practices

\section{Introduction}

The Ethiopian economy is highly dependent on agriculture and Ethiopian Agriculture is also highly dependent on livestock. Livestock play an important role in agriculture and contribute about $40 \%$ to the Agricultural economy excluding the values of draught power and manure [1]. Livestock farming supplies meat, milk, manure, hide and skin and serves as income source. Cattle fattening is an effective tool for poverty alleviation and has become an important business for smallholder farmers as well as urban dwellers in Ethiopia. Ethiopia's domestic meat consumption for 2015 has been estimated at $2.5 \mathrm{~kg} /$ capita per year for beef and veal, $1.3 \mathrm{~kg} /$ capita per year for sheep meat and $0.6 \mathrm{~kg} /$ capita per year for poultry meat and $0.0 \mathrm{~kg} /$ capita per year for pork meat. About 21.81 million animals $(499,841$ cattle, 3,539,278 sheep, 2,421,576 goat $15,339,804$ poultry and 4,625 camels) were slaughtered by households [2]. The consumption practice of meat in Ethiopia has associated with cultural practices and it plays important role in cultural and/or religious ceremonies and its cultural symbolic weight is significantly greater than most other food [3].

Beef productivity in Ethiopia constrained by different factor these include feed shortage, poor genetic resource in terms of productivity, poor management, prevalence of animal disease unfavorable socio-economic factors, traditional production system, poor selection practice and lack of livestock policy [4]. To increase beef production and improve beef quality it is important to improve beef cattle production sector by designing and implement breeding strategy. Beef yield and quality is the result of management practice and breed difference. In different parts of Ethiopia, backyard cattle fattening using locally available feed resources is practiced by traditional and indigenous systems [5]. North Shoa Zone known by its high-quality beef and cattle fattening is a tradition and widely practiced. There is information gap on husbandry practice of beef cattle in the zone. Therefore, the objective of the present study was to assess indigenous beef cattle husbandry practices in North Shoa zone.

\section{Materials and Methods}

The study was carried out in the North Shoa Administrative Zones of Amhara Regional State. The area is situated approximately between $38^{\circ} 40^{\prime} 2^{\prime \prime}$ to $40^{\circ} 6^{\prime} 36^{\prime \prime}$ E longitude $68^{\circ} 43^{\prime} 46^{\prime \prime}$ to $10^{\circ}$ $43^{\prime} 35^{\prime \prime}$ latitude and 38 $28^{\prime} \mathrm{E}$ and $40^{\circ} 5^{\prime}$ E longitude. The zone has a total surface area of about 16,193.6 square kilometers, 
comprising the highland masses in the west and the lowlands in the east. The topography of the area is characterized by flat to undulating and hilly landscapes, with contrasting tropical, subtropical and temperate climates. From the total of 22 districts and 5 town administrations, 6 districts (Minjar shenkora (39 46 '54"

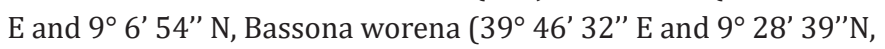

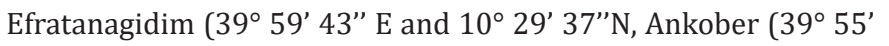
6" E and 9 $9^{\circ} 47^{\prime} 4^{\prime \prime} \mathrm{N}$, Moretna jiru (39 $19^{\prime} 24^{\prime \prime} \mathrm{E}$ and $10^{\circ} 6^{\prime} 2^{\prime \prime} \mathrm{N}$ and Menzgera midir (39 $49^{\prime} 45^{\prime \prime}$ E and $10^{\circ} 33^{\prime} 25^{\prime \prime} \mathrm{N}$ )) were purposely selected based on the distribution of cattle population and agro ecological zones. A total of 490 households were selected by a simple random sampling technique for individual interviews. The study design was formal survey based on focus group discussion and individual interview using semi structured questionnaire Elders, village leaders and individuals endowed with extensive knowledge on socio economic situation and cattle husbandry systems were selected in consultation with local agricultural extension for focus group discussions. SPSS software was used to analyze the collected data.

\section{Result and Discussion}

\section{Management practice of growing calves}

Feeding of growing calves has very important effect for the efficiency of Beef production. Giving supplementary feed for growing calves will improve bone and muscle development of Beef cattle and intern improve Beef production efficiency. According to the result indicated in Table 1, Majority of respondents $(80.7 \%$, $78.3 \%, 65.0 \%, 81.7 \%, 40.0 \%$ and $75.0 \%$ ) in Minjar shenkora, Bassonaworena, Menzgera midir, Ankober, Moretna jiru and Efratana gidim respectively, provide supplementary feed for their calves. The overall percentage of respondent who provide supplementary feed for their calves was $70.0 \%$. The respondents who manage their calves separately were $26.1 \%$ and the rest $73.9 \%$ did not practice separation.

Table 1: Management practice of growing calves.

\begin{tabular}{|c|c|c|c|c|c|c|c|c|}
\hline \multirow{2}{*}{ Variables } & \multicolumn{6}{|c|}{ Districts } \\
\cline { 2 - 8 } & $\begin{array}{c}\text { Minjar } \\
\text { Shenkora }\end{array}$ & $\begin{array}{c}\text { Bassona } \\
\text { worena }\end{array}$ & Menzgera midir & Ankober & Moretnajiru & Efratanagidim & Total \\
\hline \multicolumn{7}{|c|}{ Supplementation practice } \\
\hline $\begin{array}{c}\text { Use } \\
\text { supplementary } \\
\text { feed }\end{array}$ & 80.7 & 78.3 & 65.0 & 81.7 & 40.0 & 75.0 & 70.0 \\
\hline $\begin{array}{c}\text { No } \\
\text { supplementation }\end{array}$ & 19.3 & 21.7 & 35.0 & 18.3 & 60.0 & 25.0 & 30.0 \\
\hline Separate calves & 10.3 & 3.3 & 22.0 & 1.7 & 51.7 & 66.7 & 26.1 \\
\hline No separation & 89.7 & 96.7 & 78.0 & 98.3 & 48.3 & 33.3 & 73.9 \\
\hline
\end{tabular}

\section{Breed Type and Culling Practice of Local Cattle}

Based on the result revealed in Table 2, fattening activities were low in most districts. Majority of respondents (91.4, 60.4, 91.7, 51.7 and 56.7\%) in Minjar shenkora, Bassonaworena, Menzgera midir, Ankober and Efratana gidim respectively use exotic cattle for fattening it might be due to exotic animals are larger in size and preferred by farmers for fattening but $80 \%$ of respondents in Moretna jiru fatten local cattle. The overall percentages of respondents who fatten local cattle were 38.1.
According to focus group discussion most respondents have not practice recording information about health status, body condition and financial records during fattening. Respondents in Minjar shenkora (93.2\%), Bassonaworena (100\%), Menzgera midir (90\%), Ankober (85\%), Moretna jiru (71.9\%) and Efratana gidim (85\%) practice culling in different reasons. The main reasons of culling animals were aging (52.2\%), Infertility (10.3\%), unhealthy (22.8\%), deformed conformation (6.2\%) and unwanted color $(0.3 \%)$. The replacement method of culled cattle was through own production (48.6\%), bought (49.5\%) and credit (0.3\%).

Table 2: Breed type and culling practices of local cattle.

\begin{tabular}{|c|c|c|c|c|c|c|c|}
\hline \multirow{2}{*}{ Variables } & \multicolumn{7}{|c|}{ Districts } \\
\hline & Minjar shenkora & Bassona worena & Menzgera midir & Ankober & Moretnajiru & Efratanagidim & Total \\
\hline \multicolumn{8}{|c|}{ Breed type used for fattening } \\
\hline Local & 8.6 & 40.0 & 8.3 & 48.3 & 80.0 & 43.3 & 38.1 \\
\hline Exotic & 91.4 & 60.0 & 91.7 & 51.7 & 20.0 & 56.7 & 61.9 \\
\hline \multicolumn{8}{|c|}{ Culling practice } \\
\hline Yes & 93.2 & 100 & 90 & 85 & 71.9 & 85 & 87.6 \\
\hline No & 6.8 & 0 & 10 & 15 & 28.9 & 15 & 12.4 \\
\hline \multicolumn{8}{|c|}{ Reasons of culling } \\
\hline Age & 50.9 & 96.7 & 29.1 & 36.2 & 34.1 & 60.8 & 52.5 \\
\hline
\end{tabular}




\begin{tabular}{|c|c|c|c|c|c|c|c|c|}
\hline Unhealthy & 23.6 & 1.7 & 16.4 & 34.5 & 61.0 & 9.8 & 22.8 \\
\hline $\begin{array}{c}\text { Infertility } \\
\text { Deformed } \\
\text { conformation }\end{array}$ & 23.6 & 0 & 25.5 & 1.7 & 0 & 9.8 & 10.3 \\
\hline Unwanted color & 0 & 0 & 3.6 & 25.9 & 4.9 & 0 \\
\hline Age and unhealthy & 0 & 0 & 0 & 1.7 & 0 & 0.2 \\
\hline \multicolumn{2}{|c|}{} & 1.7 & 25.4 & 0 & 0 & 19.6 & 7.8 \\
\hline Own production & 11.9 & 91.7 & 55.4 & 66.7 & 39.1 & 21.6 & 48.6 \\
\hline Bought & 88.1 & 6.7 & 44.6 & 33.3 & 60.9 & 68.6 & 49.5 \\
\hline Not replaced & 0 & 0 & 0 & 0 & 0 & 9.8 & 1.5 \\
\hline Credit & 0 & 1.7 & 0 & 0 & 0 & 0.3 \\
\hline
\end{tabular}

Income Generation and Young Calves' Utilization Practice

According to the respondents report most respondents in Menzgera midir (36.7\%), Ankober (35.0\%), Moretna jiru (71.7\%) and Efratanagidim (48.3\%) sold castrated bull when they need money but those respondents sold crop when they need money soon except Menzgera midir (Table 3). However, respondents

Table 3: Income generation and young calves' utilization.

\begin{tabular}{|c|c|c|c|c|c|c|c|}
\hline \multirow{2}{*}{ Variables } & \multicolumn{7}{|c|}{ Districts } \\
\hline & Minjar shenkora & Bassona worena & Menzgera midir & Ankober & Moretnajiru & Efratanagidim & Total \\
\hline \multicolumn{8}{|c|}{ Income generation } \\
\hline Calves & 25.4 & 0 & 23.3 & 33.3 & 5.7 & 11.7 & 16.8 \\
\hline Bull & 11.9 & 0 & 21.7 & 20.0 & 11.3 & 18.3 & 13.9 \\
\hline Cow & 20.3 & 0 & 0 & 1.7 & 7.5 & 0 & 4.8 \\
\hline Castrated ox & 10.2 & 0 & 36.7 & 35.0 & 71.7 & 48.3 & 33.0 \\
\hline Sheep/goat & 32.2 & 100 & 18.3 & 10.0 & 3.8 & 21.7 & 31.5 \\
\hline \multicolumn{8}{|c|}{ young calves' utilization } \\
\hline Sale & 65.5 & 39.0 & 20.0 & 58.3 & 31.7 & 50.0 & 43.8 \\
\hline $\begin{array}{l}\text { keep for } \\
\text { production }\end{array}$ & 34.5 & 5.1 & 53.3 & 6.7 & 58.3 & 25.0 & 30.5 \\
\hline keep fattening & 0 & 55.9 & 26.7 & 35.0 & 10.0 & 25.0 & 25.7 \\
\hline
\end{tabular}

\section{Health Management Practice}

The overall percentage of the respondents who prefer modern treatment was 85\% which in Minjar shenkora (96.7\%), Bassonaworena (90\%), Menzgera midir (58.3\%), Ankober (74.6\%), Moretna jiru (98.3\%) and Efratana gidim (91.7\%) take their animals to clinic when disease outbreaks (Table 4). This result was similar with Hassen [9] who reported 58.54\% preferred the government service, $21.14 \%$ liked both services equally and $20.33 \%$ preferred the private service. About $47.22 \%$ of farmers preferred government service because of cost. Nontechnical constraints of animal health such as insufficient money to purchase drugs or vaccines were also reported on the review from Minjar shenkora and Bassona worena sold sheep/goat when they need money. Based on focus group discussion the price of cattle was fluctuated in all districts. In all studied areas the highest price of the fattening cattle was recorded February - may, on the other hand the low price was studied in Jun - august. The price of cattle differed according to sex, body conformation and age of cattle [6-8]. Most respondents (43.8\%) sold calves when they reach to market. 
Table 4: Health management practices.

\begin{tabular}{|c|c|c|c|c|c|c|c|}
\hline \multirow{2}{*}{ Variables } & \multicolumn{7}{|c|}{ Districts } \\
\hline & Minjar shenkora & Bassona worena & Menzgera midir & Ankober & Moretnajiru & Efratanagidim & Total \\
\hline \multicolumn{8}{|c|}{ Treatment methods } \\
\hline Modern & 96.7 & 90.0 & 58.3 & 74.6 & 98.3 & 91.7 & 85.0 \\
\hline Traditional treatment & 3.3 & 1.7 & 5.0 & 20.3 & 0 & 0 & 5.0 \\
\hline Recover by itself & 0 & 0 & 0 & 5.1 & 0 & 0 & 0.8 \\
\hline Prevention & 0 & 0 & 6.7 & 0 & 1.7 & 0 & 1.4 \\
\hline $\begin{array}{l}\text { Both modern and } \\
\text { traditional }\end{array}$ & 0 & 8.3 & 30.0 & 0 & 0 & 8.3 & 7.8 \\
\hline \multicolumn{8}{|c|}{ Veterinary services } \\
\hline $\begin{array}{c}\text { Woreda agricultural } \\
\text { office }\end{array}$ & 16.7 & 0 & 58.3 & 23.2 & 0 & 30.0 & 21.4 \\
\hline Kebeles & 80.0 & 100 & 41.7 & 60.7 & 100 & 70.0 & 75.5 \\
\hline Private & 3.3 & 0 & 0 & 16.1 & 0 & 0 & 3.1 \\
\hline \multicolumn{8}{|c|}{ Vaccination practice } \\
\hline Vaccination & 98.3 & 95.0 & 100 & 67.8 & 100 & 75.0 & 89.4 \\
\hline No vaccination & 1.7 & 5.0 & 0 & 32.2 & 0 & 25.0 & 10.6 \\
\hline \multicolumn{8}{|c|}{ Time of vaccination } \\
\hline $\begin{array}{l}\text { After the disease } \\
\text { outbreak }\end{array}$ & 31.6 & 22.8 & 16.7 & 30.0 & 3.3 & 15.6 & 19.4 \\
\hline $\begin{array}{c}\text { After some animals } \\
\text { died }\end{array}$ & 3.5 & 0 & 10.0 & 0 & 0 & 4.4 & 3.1 \\
\hline $\begin{array}{l}\text { Before the disease } \\
\text { outbreak }\end{array}$ & 64.9 & 77.2 & 73.3 & 70.0 & 96.7 & 80.0 & 77.4 \\
\hline \multicolumn{8}{|c|}{ Reason for death of animal } \\
\hline Parasite and disease & 67.8 & 12.5 & 75.0 & 34.2 & 74.6 & 56.7 & 55.1 \\
\hline Feed poisoning & 5.1 & 0 & 13.3 & 0 & 3.4 & 6.7 & 5.1 \\
\hline Predators & 1.7 & 0 & 0 & 0 & 0 & 8.3 & 1.8 \\
\hline Deformity & 0 & 0 & 1.7 & 0 & 18.6 & 28.3 & 8.7 \\
\hline Unknown reason & 25.4 & 87.5 & 10.0 & 65.8 & 3.4 & 0 & 29.2 \\
\hline
\end{tabular}

\section{Feed Conservation and Grazing Management}

Most of the farmer used owns grazing land rather than renting and these grazing lands have no any fences in most cases. According to current study most of the interviewed households $(64.3,53.3$, 47.5, 51.7, 82.2 and 55. 0) \% of Minjar shenkora, Bassonaworena, Menzgera midir, Ankober, Moretna jiru and Efratana gidim respectively used private grazing land for their cattle. The overall percentage of respondents who used private grazing land was
$57.7 \%$. As indicated in Table 5, the coverage of communal grazing land in all studied areas was very low. This shows that the size of communal grazing lands was varied in different districts and the respondents also reported that the status of both private and communal grazing land is becoming decreased, this result agrees with Abdi Etafa, Alemayehu \& Dawit [11-13]. The respondent reported that the main cause of decreasing of the grazing land was the expansion of farm.

Table 5: Feed conservation and grazing management.

\begin{tabular}{|c|c|c|c|c|c|c|c|c|}
\hline \multirow{2}{*}{ Variables } & \multicolumn{7}{|c|}{ Districts } \\
\cline { 2 - 8 } & $\begin{array}{c}\text { Minjar } \\
\text { shenkora }\end{array}$ & $\begin{array}{c}\text { Bassona } \\
\text { worena }\end{array}$ & $\begin{array}{c}\text { Menzgera } \\
\text { midir }\end{array}$ & Ankober & Moretnajiru & Efratanagidim & Total \\
\hline \multicolumn{7}{|c|}{ Grazing land ownership } \\
\hline Communal & 35.7 & 0 & 25.4 & 11.7 & 0 & 28.3 & 16.6 \\
\hline Own & 64.3 & 53.3 & 47.5 & 51.7 & 82.2 & 17.8 & 3.3 & 57.7 \\
\hline Purchased & 0 & 0 & 8.5 & 36.7 & 0 & 13.3 & 14.4 \\
\hline $\begin{array}{c}\text { Combination of } \\
\text { above }\end{array}$ & 0 & 46.7 & 18.6 & 0 & 0 & 13.3 \\
\hline
\end{tabular}




\section{Journal of Dairy \& Veterinary Sciences}

\begin{tabular}{|c|c|c|c|c|c|c|c|}
\hline \multicolumn{8}{|c|}{ Feed conservation practice } \\
\hline Conserve & 94.9 & 100 & 100 & 100 & 90 & 100 & 97.5 \\
\hline No conservation & 5.1 & 0 & 0 & 0 & 10 & 0 & 2.5 \\
\hline \multicolumn{8}{|c|}{ Type of conserved feed } \\
\hline Straw & 80.4 & 1.7 & 8.3 & 25.0 & 60.4 & 8.3 & 29.5 \\
\hline Hay & 11.1 & 0 & 8.3 & 5.0 & 0 & 0 & 2.6 \\
\hline $\begin{array}{l}\text { Both straw and } \\
\text { hay }\end{array}$ & 17.9 & 98.3 & 83.3 & 70.0 & 39.6 & 91.7 & 67.9 \\
\hline \multicolumn{8}{|c|}{ Grazing management } \\
\hline $\begin{array}{l}\text { Have a } \\
\text { caretaker }\end{array}$ & 88.1 & 100 & 93.3 & 96.7 & 73.3 & 91.7 & 90.5 \\
\hline No caretaker & 11.9 & 0 & 6.7 & 3.3 & 26.7 & 8.3 & 9.5 \\
\hline Cattle alone & 18.9 & 11.7 & 42.9 & 63.8 & 39.5 & 9.1 & 30.8 \\
\hline $\begin{array}{l}\text { With other } \\
\text { animals }\end{array}$ & 81.1 & 88.3 & 57.1 & 36.2 & 60.5 & 90.9 & 69.2 \\
\hline \multicolumn{8}{|c|}{ Grazing in dry season } \\
\hline Free grazing & 29.8 & 80.0 & 61.7 & 74.1 & 60.0 & 48.3 & 59.1 \\
\hline Semi grazing & 21.1 & 20.0 & 25.0 & 25.9 & 32.0 & 43.3 & 27.8 \\
\hline Stalling & 49.1 & 0 & 13.3 & 0 & 8.0 & 8.3 & 13.0 \\
\hline \multicolumn{8}{|c|}{ Grazing in wet season } \\
\hline Free grazing & 17.5 & 3.3 & 41.7 & 37.9 & 0 & 8.3 & 18.9 \\
\hline Semi grazing & 14.0 & 91.7 & 38.3 & 58.6 & 79.5 & 70.0 & 58.1 \\
\hline Stalling & 68.4 & 5.0 & 20.0 & 3.4 & 20.5 & 21.7 & 23.0 \\
\hline
\end{tabular}

$97.5 \%$ of respondent save feed when there is plenty of feed. According to the result indicated in Table 5, Majority of the feed resources which saved by the respondent were straw, hay and both straw and hay $(29.5 \%, 2.6 \%$ and $67.9 \%)$ respectively. This indicated that most farmers used both straw and hay. Present result in agreement to [14] that indicate natural pasture were the major feed resource and contributes $92.6 \%$ as feed resource and ranked $1^{\text {st }}$ in both dry and wet season of year followed by crop residues contribute $58.1 \%$ of total feed resource and ranked 2 nd in highland and mid-altitude areas. Most respondents in Minjar shenkora, Bassonaworena, Menzgera midir, Moretna jiru and Efratana gidim (81.1, 88.3, 57.1, 60.5, and 90.5) \% herd cattle with other animals but major respondents (63.8\%) from Ankober district were herd their cattle separately. The most type of feeding system reported by the respondents was free grazing, semi grazing and stalling. According to respondent most herding systems were (59.1 and 58.1\%) in dry and wet season respectively.

\section{Toxic Plants}

There are different types of toxic plants which poison animals but the species and distribution of such toxic plants were different across district. The result revealed in Table 6, Maget (21.1\%), young sorghum leaf (48.9\%), gurte (22.6\%), alumma (3.8) and akenchira (3.8) were the main toxic plants for cattle. These toxic plants distribution was varied in different agro ecological zone.

Table 6: Toxic plants.

\begin{tabular}{|c|c|c|c|c|c|c|c|}
\hline \multirow{2}{*}{ Variables } & \multicolumn{7}{|c|}{ Districts } \\
\hline & Minjar shenkora & Bassona worena & Menzgera midir & Ankober & Moretnajiru & Efratanagidim & Total \\
\hline \multicolumn{8}{|c|}{ Is there toxic plant for your cattle } \\
\hline Yes & 45 & 16.7 & 33.3 & 40 & 45.8 & 50 & 38.4 \\
\hline No & 55 & 83.3 & 66.7 & 60 & 54.2 & 50 & 61.6 \\
\hline \multicolumn{8}{|c|}{ Local name of toxic plants } \\
\hline Maget & 0 & 30 & 100 & 20.8 & 0 & 0 & 21.1 \\
\hline $\begin{array}{l}\text { Young sorghum } \\
\text { leaf }\end{array}$ & 57.1 & 0 & 0 & 0 & 90.5 & 100 & 48.9 \\
\hline Gurte & 7.1 & 70 & 0 & 79.2 & 9.5 & 0 & 22.6 \\
\hline Aluma & 17.9 & 0 & 0 & 0 & 0 & 0 & 3.8 \\
\hline Akenchira & 17.9 & 0 & 0 & 0 & 0 & 0 & 3.8 \\
\hline
\end{tabular}




\section{Supplementary Feeds and Practice of Supplementation}

Majority of (96.1\%) of respondents provide supplementary feed for their cattle and wheat bran $(22.8 \%)$, oil seed cake $(5.5 \%)$, grain $(2.9 \%)$, crop residues $(55.5 \%)$, salt $(11 \%)$ and food refuse $(2.3 \%)$ were the main supplementary feeds in the study areas (Table 7). Most respondents (85\%) in Minjar shekora supplement their cattle with wheat bran but respondents from Bassonaworena (95.5\%), Ankober (61.4\%), Moretna jiru (37.5\%) and Efratana gidim $(91.7 \%)$ supplement their cattle with crop residues. All studied districts supplement their cattle with salt except Efratana gidim. Based on focus group discussion, majority of the respondents in all studied areas were not used concentrate mix, fodder crops and grass pea as supplementary feed but "atella", wheat bran and Noug cake mix and conserved hay were used as supplementary feed for their cattle in both dry and wet season however, 17.9 and $11.6 \%$ of respondents supplement their cattle only in dry and wet season respectively. Similar to the present result Fekadu [15] report farmers in Gonder also use 41.4\%, 37.1\% and 21.5 farmer use wheat straw, hay and nugcake respectively as supplementary feed and in the contrary to the current result farmers in Gonder never use atella as a supplementary feed. The frequency of providing supplementary feed was varied in across districts. 73.3\% (Minjar shenkora), 43.9\% (Ankober) and 71.7\% (Bassonaworena) respondents supplement supplementary feed daily but $45.5 \%$ and $52.8 \%$ of respondents in Moretna jiru and Menzgera midir provide supplementary feed twice a day and as the feed available respectively. In general, $60.0 \%$ respondents provide supplementary feed twice a day. This result is also reported by Tsegay and Mengistu which was almost all commercial farms was feed twice and only few farms were followed three times of feeding.

Table 7: Supplementary feeds supplementation practice.

\begin{tabular}{|c|c|c|c|c|c|c|c|}
\hline \multirow{2}{*}{ Variables } & \multicolumn{7}{|c|}{ Districts } \\
\hline & Minjar shenkora & Bassona worena & Menzgera midir & Ankober & Moretnajiru & Efratanagidim & Total \\
\hline \multicolumn{8}{|c|}{ Do you provide supplementary feed } \\
\hline Yes & 100 & 100 & 88.3 & 95.0 & 93.3 & 100 & 96.1 \\
\hline No & 0 & 0 & 11.7 & 5.0 & 6.7 & 0 & 3.9 \\
\hline \multicolumn{8}{|c|}{ Supplementary feeds } \\
\hline Wheat bran & 85.0 & 0 & 41.5 & 0 & 1.8 & 8.3 & 22.8 \\
\hline Oil seed cake & 0 & 3.3 & 3.8 & 0 & 26.8 & 0 & 5.5 \\
\hline Grain & 1.7 & 0 & 3.8 & 12.3 & 0 & 0 & 2.9 \\
\hline Crop residues & 10 & 95.5 & 34.0 & 61.4 & 37.5 & 91.7 & 55.5 \\
\hline Salt & 1.7 & 1.7 & 9.4 & 26.3 & 28.6 & 0 & 11.0 \\
\hline Food refuse & 1.7 & 0 & 7.5 & 0 & 5.4 & 0 & 2.3 \\
\hline \multicolumn{8}{|c|}{ When you provide additional feed } \\
\hline Dry season & 31.7 & 0 & 39.6 & 7.0 & 10.7 & 20.0 & 17.9 \\
\hline Wet season & 25.0 & 1.7 & 15.1 & 3.5 & 16.1 & 8.3 & 11.6 \\
\hline In both season & 43.3 & 98.3 & 45.3 & 89.5 & 73.2 & 71.1 & 70.5 \\
\hline \multicolumn{8}{|c|}{ Frequency of feeding supplementary feed } \\
\hline Daily & 73.3 & 71.7 & 17.0 & 43.9 & 16.4 & 20.0 & 41.2 \\
\hline Twice a day & 8.3 & 10.0 & 30.2 & 28.1 & 45.5 & 60.0 & 30.1 \\
\hline $\begin{array}{c}\text { Based on } \\
\text { availability }\end{array}$ & 18.3 & 18.3 & 52.8 & 28.1 & 38.2 & 20.0 & 28.7 \\
\hline
\end{tabular}

\section{Watering Practice}

Differences in watering frequency across seasons constituted one of the most distinctive elements of livestock management. The overall watering frequency in dry season was $52.2 \%, 47.5 \%$ and $0.3 \%$ and in wet season $31.9 \%, 64.2 \%$ and $3.9 \%$ twice, once and three times a day respectively. According to the respondents report in Table 8, Minjar shenkora, Bassonaworena and Efratana gidim $(65.5,80$ and 80$) \%$ respectively provide water once a day in dry season but Menzgera midir (81.7\%), Ankober (75\%) and
Moretna jiru (81.7\%) provide water twice a day in dry season. $64.2 \%$ of respondents provide water for their cattle twice a day in wet season. This result is disagreeing with Azage [16]. According to the focus group discussion it was observed that when water is freely available, particularly when livestock are grazing near water resources during the dry season and no herding, frequency of drinking increased but drinking was in small quantities at any one time and about $82 \%$ of the respondents revealed that fattening cattle have got access to the water source within $<1.6$ $\mathrm{km}$ distance [17]. 
Table 8: Watering practice.

\begin{tabular}{|c|c|c|c|c|c|c|c|}
\hline \multirow[b]{2}{*}{ Variables } & \multicolumn{7}{|c|}{ Districts } \\
\hline & $\begin{array}{c}\text { Minjar } \\
\text { shenkora }\end{array}$ & $\begin{array}{c}\text { Bassona } \\
\text { worena }\end{array}$ & $\begin{array}{l}\text { Menzgera } \\
\text { midir }\end{array}$ & Ankober & Moretnajiru & Efratanagidim & Total \\
\hline \multicolumn{8}{|c|}{ Dry season } \\
\hline Twice a day & 35.0 & 20.0 & 81.7 & 75.0 & 81.7 & 20.0 & 52.2 \\
\hline Once a day & 65.0 & 80.0 & 18.3 & 25.0 & 16.7 & 80.0 & 47.5 \\
\hline $\begin{array}{l}\text { Three time a } \\
\text { day }\end{array}$ & 0 & 0 & 0 & 0 & 1.7 & 0 & 0.3 \\
\hline \multicolumn{8}{|c|}{ Wet season } \\
\hline Twice a day & 36.7 & 56.7 & 13.3 & 45.0 & 31.7 & 8.3 & 31.9 \\
\hline Once a day & 61.7 & 43.3 & 65.0 & 55.0 & 68.3 & 91.7 & 64.2 \\
\hline $\begin{array}{l}\text { Three time a } \\
\text { day }\end{array}$ & 1.7 & 0 & 21.7 & 0 & 0 & 0 & 3.9 \\
\hline
\end{tabular}

\section{Housing System}

The result revealed in Table 9, majority of respondents $(66.1 \%)$ stay their cattle at day and nighttime and the remaining $23.5 \%, 4.8 \%$ and $5.6 \%$ of respondents stay their cattle for nighttime, daytime only and not house at all respectively. $33.3 \%$ of respondents from Minjar shenkora construct a simple shed for their cattle. $95.1 \%, 70 \%, 66.7 \%, 50 \%, 31.7 \%$ and $62.5 \%$ of respondents in Minjar shenkora, Bassonaworena, Menzgera midir, Ankober, Moretna jiru and Efratana gidim respectively keep their

Table 9: Beef cattle housing system. cattle at separate house. According to the result Minjar shenkora, Bassonaworena, Menzgera midir and Efratana gidim respectively have separate house for their fattening cattle but respondents from Ankober have animal house which was join with human house but separated. Most respondents not keep cattle with human house. This result was also reported by Shitahun, three types of houses which had been used to keep the fattening cattle were separated room in the family house (56\%), separated house constructed for the cattle (32\%), and enclosed barn with simple shed (12\%) of the respondents.

\begin{tabular}{|c|c|c|c|c|c|c|c|}
\hline \multirow{2}{*}{ Variables } & \multicolumn{7}{|c|}{ Districts } \\
\hline & Minjar shenkora & Bassona worena & Menzgera midir & Ankober & Moretnajiru & Efratanagidim & Total \\
\hline \multicolumn{8}{|c|}{ When your cattle stay in the house } \\
\hline For night time only & 23.3 & 0 & 26.7 & 41.7 & 43.1 & 5.4 & 23.5 \\
\hline For day time only & 3.3 & 0 & 8.3 & 1.7 & 6.9 & 8.8 & 4.8 \\
\hline For day and nighttime & 40.0 & 100 & 65.0 & 56.7 & 50.0 & 85.7 & 66.1 \\
\hline No house at all & 33.3 & 0 & 0 & 0 & 0 & 0 & 5.6 \\
\hline \multicolumn{8}{|l|}{ Type of house } \\
\hline Separately & 95.1 & 70 & 66.7 & 50.0 & 31.7 & 62.5 & 60.8 \\
\hline Join with human house & 4.9 & 30 & 11.7 & 50.0 & 48.3 & 37.5 & 31.8 \\
\hline Together with human & 0 & 0 & 21.7 & 0 & 20.0 & 0 & 7.4 \\
\hline
\end{tabular}

\section{Conclusion}

The study showed that most of the farmers give supplementation for growing calves and fattening animals and no separation and manage the growing calves together with other animals and farmers prefer modern treatment and governmental clinic. With the exception of Moretinajiru woreda the farmers prefer exotic animals for fattening. Age was the main reason for culling. Most farmer sale castrated ox, sheep and goat to generate income. The major feed resources in study areas were crop residues, conserved hay, industrial by products and natural grazing. Most producers in all districts keep their cattle in separate house and have care taker for their animals during grazing and watering frequency across seasons was different in all districts.

\section{References}

1. Aleme Asresie, Lemma Zemedu (2015) Contribution of Livestock Sector in Ethiopian Economy: A Review. Advances in Life Science and Technology 29: 79-90.

2. CSA (2016) (Central Statistical Authority) Federal Democratic Republic of Ethiopia Central Statistical Agency. Agricultural Sample Survey for the year 2010/11. Report on Livestock and Livestock Characteristics. Addis Ababa, Ethiopia, 2: 190.

3. Semeneh Seleshe, Cheorun JO, Mooha Lee (2014) Meat Consumption Culture in Ethiopia. Korean J Food Sci An 34(1): 7-13.

4. Amistu K, Temesgen M, Alemu A, Tarekegn W (2016) Assessment of Beef Cattle Fattening and Marketing System and Contribution to Household Food Security in Case of Lemmo Woreda, Hadiya Zone, Southern Ethiopia. Journal of Marketing and Consumer Research 29: $1-10$. 
5. Adugna T (2008) Feed resources and feeding management: a manual for feedlot operators and development workers. Ethiopian Sanitary \& Phytosanitary Standards and Livestock \& Meat marketing Program (SPS-LMM) Texa Agricultural Experiment Station (TAES)/Texas A \& M University System, Addis Ababa, Ethiopia.

6. Miote SN, Mdoe NSY, Isinika AC, Mtenga LA (2013) Profitability analysis of small-scale beef cattle fattening in the Lake Zone in Tanzania Journal of Agricultural Economics and Development 2(5): 203-216.

7. Shitahun Mulu (2009) Feed Resources Availability, Cattle Fattening Practices and Marketing System in Bure Woreda, Amhara Region, Ethiopia. Faculty of Dry Land Agriculture and Natural Resources Department of cattle, Range and Wildlife Sciences. Mekelle University, Ethiopia.

8. Tsegay Teklebrhan, Mengistu Urge (2013) Assessment of commercial feedlot finishing practices at eastern Shoa, Ethiopia. Open Journal of cattle Sciences 3(4): 273-280.

9. Hassen Kebede, Achenef Melaku, Elias Kebede (2014) Constraints in animal health service delivery and sustainable improvement alternatives in North Gondar, Ethiopia, Onderstepoort Journal of Veterinary Research 81(1): 10.

10. Andualem Tonamo (2016) A review on cattle husbandry practices in Ethiopia. International Journal of Livestock Production 7(2): 5-11.

11. Abdi Etafa, kemalkasim, Yassin Esmael, Muleta Debela (2013) Cattle Production in West Hararghe: An Opportunity and Constraints Assessments in Darolabu, Odabultum, Gemechis and Chiro Districts, Oromia Regional State, Ethiopia. International Journal of Livestock Production Research 1(1): 1- 15.
12. Alemayehu Mengistu (2002) Forage production in Ethiopia: A case study with implications for livestock production. ESAP (Ethiopian Society of cattle Production), Addis Ababa, Ethiopia, pp. 106

13. Dawit Assefa, Ajebu Nurfeta, Sandip Banerjee (2013) Assessment of feed resource availability and livestock production constraints in selected Kebeles of Adami TulluJiddo Kombolcha District, Ethiopia. Adami Tullu Agricultural Research Center, P. O. Box 35, Ziway, Ethiopia.

14. Seid Guyo and Berhan Tamir (2014) Assessment of Cattle Husbandary Practice in Burji Woreda, Segen Zone of SNNPRs, Ethiopia. International Journal of Technology Enhancements and Emergency Research, 2(4): 2347-4289.

15. Fekadu Mengie, Tarekegn Tintagu Gizaw, Bethelehem Alemu Minalu, Yalew Tefera (2017) Study on beef cattle production management practices and constraints in Gondar town North West, Ethiopia. Int J Adv Res Biol Sci 4(8): 18-27.

16. Azage Tegegne, Zewdu Ayele, Dirk Hoekstra (2011) Farmer innovations in livestock feeding and management in semi-arid areas of Ethiopia Improving Productivity and Market Success (IPMS) Project, International Livestock Research Institute (ILRI), Addis Ababa, Ethiopia.

17. Gebre Mariam S, Amare S, Baker D, Solomon A, Davies R (2013) Study of the Ethiopian live cattle and beef value chain. ILRI Discussion Paper 23. Nairobi: International Livestock Research Institute.

\section{Your next submission with Juniper Publishers} will reach you the below assets

- Quality Editorial service

- Swift Peer Review

- Reprints availability

- E-prints Service

- Manuscript Podcast for convenient understanding

- Global attainment for your research

- Manuscript accessibility in different formats

( Pdf, E-pub, Full Text, Audio)

- Unceasing customer service

Track the below URL for one-step submission https://juniperpublishers.com/online-submission.php 